\title{
LISTENING COMPREHENSION STRATEGIES APPLIED BY ENGLISH LANGUAGE LEARNERS
}

\author{
Sitti Hadijah ${ }^{1}$ Shalawati $^{2}$ \\ ${ }^{1}$ Universitas Islam Riau \\ sittihadijah@edu.uir.ac.id
}

\begin{abstract}
This paper depicts a part of a research project, focused on exploring three listening comprehension strategies applied by the English learners in interpretative listening subject; (a) meta-cognitive strategies consist of directed attention, selective attention, planning, monitoring, and evaluation; (b) cognitive strategies include listening for gist and detail, inference, prediction, visualization, summarizing, and note-taking; (c) Social/affective strategies, such as cooperation. Hence, mixed-method research was employed to describe what listening comprehension strategies used more often by English Students at Universitas Islam Riau. Thirty-seven fresh year learners taking interpretative listening subject were encouraged to participate in this research by filling out questionnaire adopted form Cross (2009). The data collected will both qualitatively and quantitatively analyzed. Thirty-two statements included in the questionnaire were categorized intro three groups; cognitive (15), meta-cognitive (15), and socio-affective (2). The finding reveals that the learners had been familiar will the strategies and frequently apply them based on their needs in listening processes, such as before, while, and after listening.
\end{abstract}

Keywords: Listening Comprehension, Strategies, English

\section{INTRODUCTION}

Listening comprehension is active process that requires concentration, linguistic knowledge, listening strategies in order to gather or interpret information form aural input. However, to have good listening comprehension is one of challenges that is commonly encountered by many English learners, particularly for EFL (English Foreign Language) learners as it is influenced by several factors, for an example; limited exposure on listening activities. It means that the students usually have lack of listening practices because the listening activities are rarely practiced by the students because the language is not widely used in their social environment, in which more people speak in the native language, Bahasa Indoneisa rather than use the foreign language, English. Obviously, the learners get problems to be proficiency in English and master every skill in English, particularly about listening skill. Besides that, the English teachers at schools seem avoiding to teach listening skill, while reading, speaking, and writing are more often taught by many teachers. Some technical matters, lack of learning resources, limited adequate technological devices, and some other reasons are usually addressed by the teachers why they do not facilitate the students to have listening practices. 
When teaching listening subject for university students, researcher found that many students were very poor in listening comprehension. It was also supported by previous studies on the students' listening comprehension (Hadijah and Shalawati: 2016) and their barriers in listening activities, (Hadijah and Shalawati: 2017). The two studies showed that the students' limited vocabulary mastery, unfamiliarity with the English words sound, speed rate of speakers in the audio or video, and also lack of strategy in learning influence the students' success on listening activities.

In this case, the teachers need to facilitate the students to enhance their listening performances. One of the ways by encouraging the students to keep practicing their listening because some issues in vocabulary, unfamiliar sounds, speed rate of speakers can be simultaneously figured out through their practices. However, the learners also need to apply some listening strategies to help them in their listening activities because the strategies will help the learners to anticipate some problems that may appear in their listening activities.

There are numerous listening strategies that can be applied by the learners, but they have to be able to select the appropriate strategy based on their needs. Tandoc \& Tandoc (2014: 436) mentioned three types of listening strategies that can be taught to the students, such as; metacognitive strategies, cognitive strategies, social/affective strategies. All of the strategies have their own particular function on listening activities. In this case, this research was conducted to investigate what listening comprehension strategies used more often by English learners in during their practices in interpretative listening subject.

\section{REVIEW OF RELATED LITERATURE}

Fang (2008) said that listening comprehension as an active process that needs the learners/listeners to focus on meaning from the aural information and associate it with their background knowledge. In other words, listening comprehension requires learners to be able to discover meaning which should be supported by several factors, such as linguistic factors, listening strategy factors, and affective factors, (Bang and Hiver, 2016). According to Nation (2006) linguistics knowledge has essential influence towards learners listening activities. Vandergrift (2006) in Bang and Hiver (2016) state that vocabulary and grammatical understanding are key elements in listening comprehension. Then, listening strategy can also influence the students' listening proficiency in which can be very helpful for them in the process of comprehension. Students' high proficiency in listening is characterized by their flexibility in applying strategies in every phases of listening, (Vandegift and Tafaghodtari (2010) in Bang and Hiver (2016)). The last, but not least, motivation and anxiety are two affective factors that influence the learners' listening proficiency. The learners' incapability to control information, speed, and volume of speech in the audio will appear their apprehension and affect their motivation in listening activities. In this case, to be skilled in listening, the 
learners have to enhance their linguistic knowledge, be skillful in applying listening strategies, become confidence and have high motivation in listening activities.

Cross (2009) also adapted procedural framework from Mendelson (1994) to promote listening comprehension of news videotexts:

1. Identifying and analyzing learners' barriers in listening.

2. Investigating the learners' skill in applying listening materials

3. Deciding the appropriate strategies (cognitive, meta-cognitive, or socioaffective strategies) to be instructed to the students and considering appropriate tasks to apply the strategies.

4. Preparing listening materials in relation to pre-while, and post listening materials, and exercises.

5. Providing substantial practice, feedback, and consistent reviews.

6. Evaluation the instruction and making some revisions when they are needed.

7. Encouraging self-evaluation and autonomous through the listening strategies.

Cohen (2011) also stated that language learning strategies are classified into several categories; strategies for learning and use, strategies according to skill area, strategies based on function. It means that language learners need to know what sorts of learning strategies are required in their learning process, what particular strategies are required in learning different skills, and what the function of using the strategies. Then,
Graham\& Vanderplank (2011) describe about the characteristics of the strategies, as follow; (a) meta-cognitive strategies consist of directed attention, selective attention, planning, monitoring, and evaluation; (b) cognitive strategies include listening for gist and detail, inference, prediction, visualization, summarizing, and note-taking; (c) Social/affective strategies, such as cooperation.

Metacognitve strategies refer to ways to make students understand the way they learn. The strategies can positively impact the students by guiding them to develop an appropriate way of learning. The strategies consist of planning, monitoring, and evaluation. On the other hand,cognitive strategies instruction develop the thinking skills that will make students strategic, flexible learners. This strategies re commonly done by many people, such as taking a note to remember information. For some students, the strategies need to be explicitly taught, so they be able to consciously think. Besides that, they also need to have opportunity or training to practice the strategies. So the strategies can be powerful tool to enhance their success in learning. Besides that, affective strategies are learning strategies concerned with managing emotions, both negative and positive. According to Liu (2008), this type of strategy involves interaction with another person in a conversation or taking control of one's emotions. Liu (2008) also stated that skilled learners show better emotional control and have good skill in using strategies, compared to poor-skilled listeners 
who pretend to show their apprehension when facing problems in communication. statements in the questionnaire can be seen in the following table:

\section{METHOD}

This research employed mixed-method research to describe what listening comprehension strategies used more often by English Students at Universitas Islam Riau during their listening practices in Interpretative Listening subject. Questionnaire was distributed to thirty seven-fresh year students from English language education program, Universitas Islam Riau. The questionnaire used in this study adopted from Cross (2009) that consisted of 32 statements about metacognitive (15), cognitive (15), and socioaffective strategies (2). The collected data were analyzed in both qualitative and quantitative analysis. Then, the list of the

\begin{tabular}{|c|c|l|}
\hline No & $\begin{array}{c}\text { Type of } \\
\text { Strategy }\end{array}$ & \\
\hline 1. & MET & $\begin{array}{l}\text { Before I strat to listen,I have plan in my head for how I am going to } \\
\text { listen }\end{array}$ \\
\hline 2. & COG & I translate in my head as I listen \\
\hline 3. & COG & Before listening, I make predictions about the listening material based on the title \\
\hline 4. & MET & I focus harder on the text when I have trouble understanding. \\
\hline 5. & COG & I use the words I understand to guess the meaning of the words I do not understand \\
\hline 6. & MET & When my mind wanders, I recover my concentration right away \\
\hline 7. & COG & As I listen, I compare what I understand with what I know about the topic \\
\hline 8. & SOA & As I listen, I encourage myself through positive self-talk \\
\hline 9. & MET & When there is something I do not understand, I pursue trying to compensate for it \\
\hline 10. & COG & I use my experience and knowledge to help me understand \\
\hline 11. & MET & Before listening, I think of similar texts that I may have listened to. \\
\hline 12. & COG & I use my knowledge of the text organization to understand the text \\
\hline 13. & MET & I try to get back on track when I lose concentration \\
\hline 14. & COG & Before listening, I try to predict the words I am likely to hear based on the title. \\
\hline 15. & COG & As listen, I quickly adjust my interpretation if I realize that is not correct. \\
\hline
\end{tabular}

ELT-Lectura: Jurnal Pendidikan, Vol 5, No1, February 2018 


\begin{tabular}{|c|c|c|}
\hline 16. & MET & I identify my problems in listening and work on solving them. \\
\hline 17. & MET & $\begin{array}{l}\text { After listening, I think back to how I listened, and about what I might do differently } \\
\text { next time }\end{array}$ \\
\hline 18 & $\mathrm{COG}$ & After listening, I make a mental summary of what I have listened to. \\
\hline 19. & MET & When I have difficulty understanding what I hear, I give up and stop listening. \\
\hline 20. & $\mathrm{COG}$ & $\begin{array}{l}\text { I use the main idea of the text to help me guess the meaning of the words that I do } \\
\text { not understand. }\end{array}$ \\
\hline 21. & MET & I skip over words that I do not understand so that I do not miss what is said next. \\
\hline 22. & $\mathrm{COG}$ & $\begin{array}{l}\text { As I listen, I try to think in English without having to translate into my own } \\
\text { language. }\end{array}$ \\
\hline 23. & $\mathrm{COG}$ & When I guess the meaning of a word, I think back to everything else that I have \\
\hline 24. & MET & $\begin{array}{l}\text { As I listen, I periodically ask myself if I am satisfied with my level of } \\
\text { comprehension }\end{array}$ \\
\hline 25. & MET & After listening, I reflect on the listening task with my classmates. \\
\hline 26. & $\mathrm{COG}$ & I use pronunciation aspects like stress and intonation to enhance my understanding. \\
\hline 27 & MET & $\begin{array}{l}\text { Before listening, I concentrate my mind on the listening task and keep away things } \\
\text { that distract attention. }\end{array}$ \\
\hline 28. & MET & Listen to what is said without paying much attention to every new word. \\
\hline 29. & $\mathrm{COG}$ & As I listen, I try to predict incoming content using the information being delivered. \\
\hline 30. & MET & As I listen, I repeat important words mentally. \\
\hline 31. & $\mathrm{COG}$ & $\begin{array}{l}\text { I picture the setting of the conversation to understand what the speakers are talking } \\
\text { about. }\end{array}$ \\
\hline 32. & $\mathrm{SOA}$ & her and classmates about how to be a better listener of English. \\
\hline
\end{tabular}

\section{FINDINGS AND DISCUSSIONS}

To investigates the students' listening strategies, two sorts of questionnaires were distributed to the students with two main objectives; find out the students' familiarity with the strategies, and what strategies frequently applied by the students. The following information presents about three listening strategies applied by the students in their listening activities:

\subsection{Meta-cognitive Strategies}

As previously explained, metacognitive strategies are ways applied by the students to understand the way they learn elT- Lectura: Jurnal Pendidikan, Vol 5, No1, February 2018 that including three phases; planning, monitoring, and evaluating. Based on questionnaire adopted from Cross (2009), there are 15 statements in relation to the implementation of meta-cognitive strategies in listening activities:

1. Before I start to listen, I have plan in my head for how I am going to listen. (Q1)

2. I focus harder on the text when I have trouble understanding. (Q4)

3. When my mind wanders, I recover my concentration right away. (Q6)

4. When there is something I do not understand, I pursue trying to compensate for it. (Q9) 
5. Before listening, I think of similar texts that I may have listened to. (Q11)

6. I try to get back on track when I lose concentration. (Q13)

7. I identify my problem in listening and work on solving them. (Q16)

8. After listening, I think back to how I listened, and about what I might do differently next time. (Q17)

9. When I get difficult understanding what I hear, I give up and stop listening. (Q19)

10. I skip over words that I do not understand so that I do not miss what is said next. (Q21)

11. As I listen, I periodically ask myself if I am satisfied with my level of comprehension. (Q24)

12. After listening, I reflect on the listening task with my classmates. (Q25)

13. Before listening, I concentrate my mind on the listening task and keep away things that distract attention. (Q27)

14. Listen to what is said without paying much attention to every new word.(Q28)

15. As I listen, I repeat important words mentally. (Q30)

The following chart presents the frequency of meta-cognitive strategies implementation in the students' listening activities:
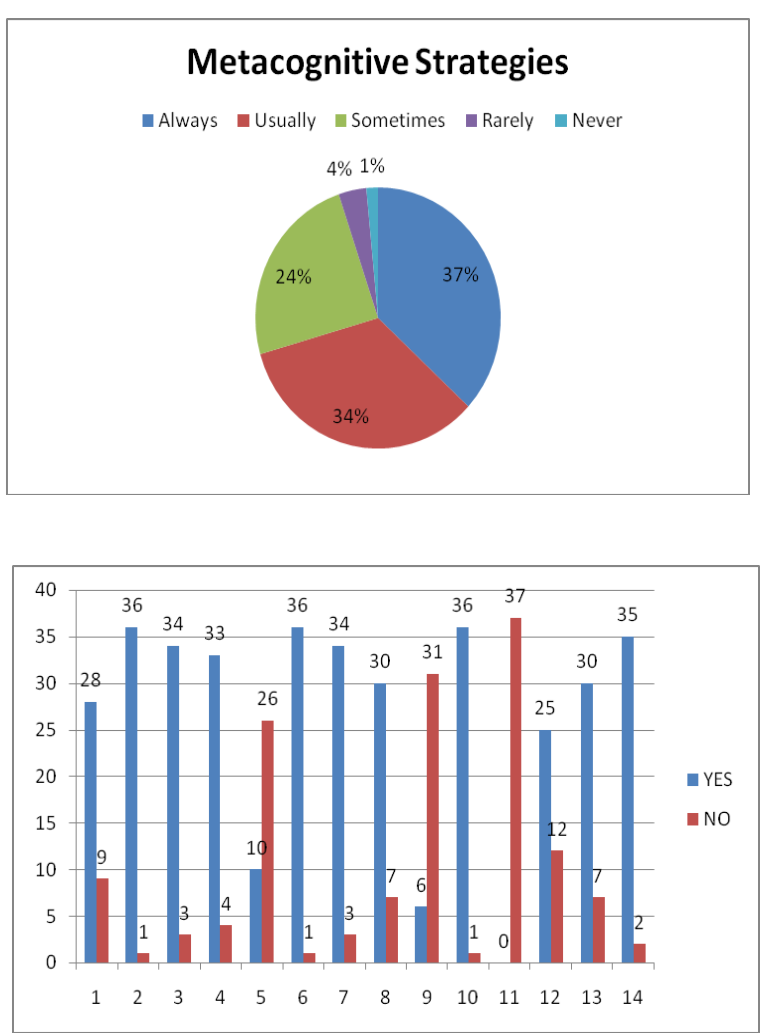

The pie chart illustrates the implementation of meta-cognitive strategies by the learners. Most of them applied the strategies, accounted to $37 \%$ and $34 \%$ for the frequency of "always" and "usually". Then, $24 \%$ of the learners sometimes run the strategies, while $5 \%$ of them were rarely and never implement the strategies.

Furthermore, detail information about the learners' responses towards the metacognitive strategies is presented in the following:

As can be seen in the chart, there are fourteen questions asked to the students in relation to the implementation of metacognitive strategies. Most of the students applied the strategies during their listening practices. There were 9 out 14 strategies had been applied by most of the students, see 
strategy no. 4, 6,9, 11,13,16,1719, 21,27, and 28. It means that the learners had been very familiar with the meta-cognitive strategies.

On the other hand, for strategy no. 24, all of the learners did not apply it in the in their listening practices. The students claimed that they did not prediocally asked themselves whether they were satisfied with their listening comprehension level. As could be seen during the students' performances in completing their listening tasks, most of the students just direcly discussed with their chairmates about the test that they had done. Sometimes, the students looked regret because they wrote wrong answers, while others were really excited that they have similar answers among the others eventhough they have no known what the appropriate answers are. The situations clearly explained that the students did not use to ask themselves about their satisfaction in doing the test. They prefer to share their experiences and ideas about the tests that they had passed.

Then, there were tens students also who tried to thnik in English without translating into Bahasa Indoneisa. This strategy weas the second less strategy of meta-cognitive selected by the students in their listening activities. It can be assumed that keep thinking in English withoug translation the information into Bahasa Indonesia was quite though to be implemented by the students. It might be affected by several facotrs, such as their weaknesses in English or unfamiliar information that they listened.
However, most of the students have already been familiar with meta-cognitive strategies to help them to be more succesful in completeing the listening tasks. Eventhough the students encountered some problems in their listening acitivities, most of the students did not give up to beat the challenges. As can be seen in the chart, there were only six students out of thiry-seven who would give up. Hence, most of the students had higher willingnes to complete all challenges in their listening activities.

\subsection{Cognitive Strategies}

Cognitive strategies require the students' process of thinking that can make them to be strategic and flexible learners. The strategies can be implemented by taking a note to remember the information. In the questionnaire adopted from Cross (2009), there are 15 statements in relation to the implementation of cognitive strategies in listening activities:

1. I translate in my heart as I listen. (Q2)

2. Before listening, I make predictions about the listening material based on the title. (Q3)

3. I use the words I understand to guess the meaning of the words I do not understand.(Q5)

4. As I listen, I compare what I understand with what I know about the topic. (Q7)

5. I use my experience and knowledge to help me understand. (Q10)

6. I use my knowledge of the text organization to understand the text. (Q12) 
7. Before listening, I try to predict the words I am likely to hear based on the title. (Q14)

8. As I listen, I quickly adjust my interpretation if I realize that is not correct.(Q15)

9. After listening, I make mental summary about what I have listened to. (Q18)

10. I use the main idea of the text to help me guess the meaning of the words that I do not understand. (Q20)

11. As I listen, I try to think in English without having to translate in my own language.(Q22)

12. When I guess the meaning of a word, I think back to everything else that I have.(Q23)

13. I use pronunciation aspects like stress and intonation to enhance my understanding. (Q26)

14. As I listen, I try to predict incoming content using the information being delivered.(Q29)

15. I picture the setting of the conversation to understand what the speakers are talking about. (Q31)

The following chart shows the frequency of applying the cognitive strategies in listening activities:

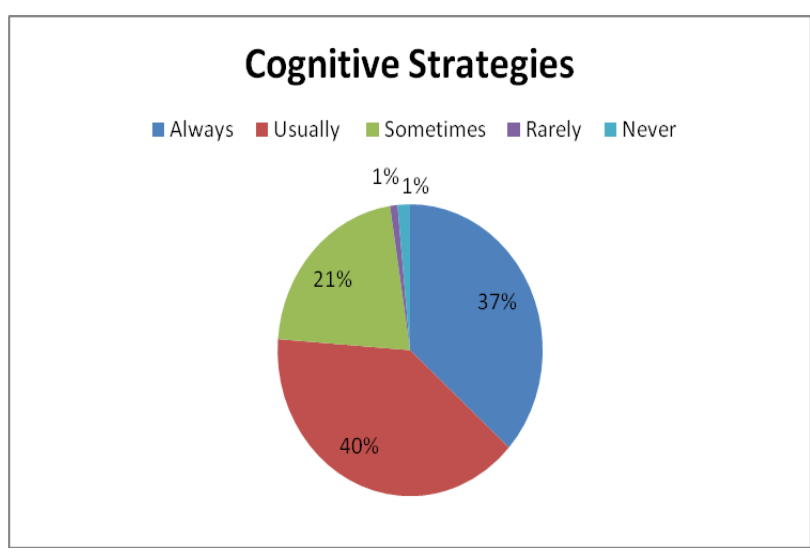

The chart indicates the implementation of cognitive strategies were dominantly applied by the learners even though it had different percentages for the frequency of applying the strategies. There were $77 \%$ of the students had run the strategies in their listening activities more frequently, compare to the rest of them who just "sometimes", "rarely", and "never".

The information about the implementation of cognitive strategies in listening activities can be seen in the following table:

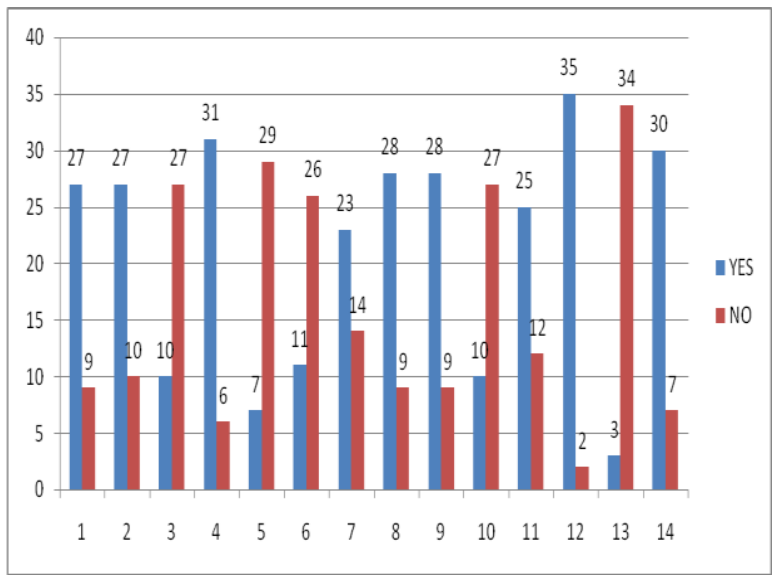

The table presents that most of the students have been very familiar with cognitive strategies in their listening 
activities. Among the fifteen statements about the strategies, there were only three statements which were only applied by less than ten students, while the rest of the strategies had been widely run. The less applied strategies were about integrating knowledge and experience, using main idea to guess words' meaning, and using pronunciation aspects to enhance their understanding.

For statements number 7, 23,29, those had been run by over than thirty learners in their listening activities which mean that they involve their background knowledge to support their comprehension towards the information that they listen. The learners activated their background knowledge by understanding the topic, guessing words' meaning, and predicting the clues. However, guessing the words' meaning was the most frequently selected by the students.

Furthermore, there were six statements, selected by 20-29 students, which indicate that the learners had also applied the strategies in their listening even though the numbers of the students were less selected, compared to the statements number 7, 22, 29. For the six-strategy, the learners did translation, prediction based on title, before listening prediction (based on title), interpretation adjustment, mental summary, and using English in thinking process.

\subsection{Socio/Affective Strategies}

Socio-affective strategies involve interaction with somebody in a conversation or taking control of one's emotions. In other words, it needs the learners' skill in controlling their emotions in doing the tasks given. In Cross's questionnaire, there were only two socio-affective strategies addressed:

1. As I listen, I encourage myself through positive self-talk. (S8)

2. I talk to my teacher and classmates about how to be a better listener of English. (S32)

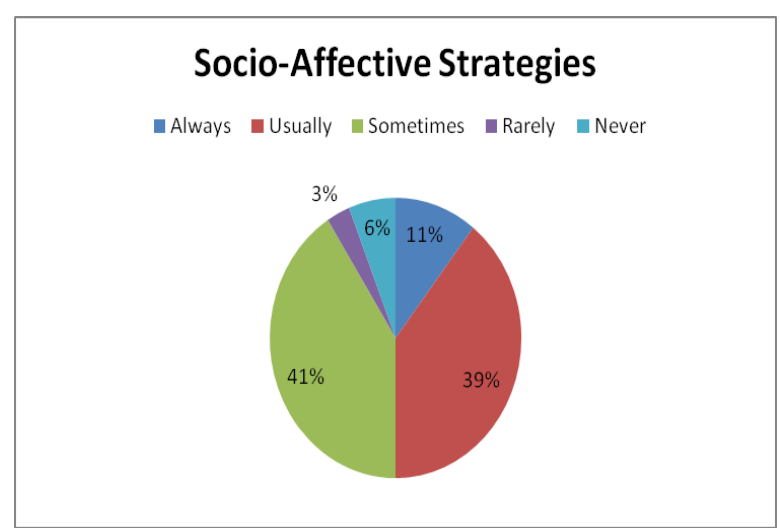

The frequency of socio-affective implementation can be seen in the following chart:

The chart depicts that $41 \%$ students applied the socio-affective strategies in their listening activities. Although, the biggest percentage of the students were "sometimes" applied, and followed by 39\% of other students "usually" worked on the strategies, and $11 \%$ students were "always" run the strategies. Then, there were only a few of them, $9 \%$ students who rarely and even never apply the strategies. For over all, the strategies were quiet common among the students.

Then, the following chart shows the learners' responses in relation to the 
implementation of socio-affective strategies in more detail:

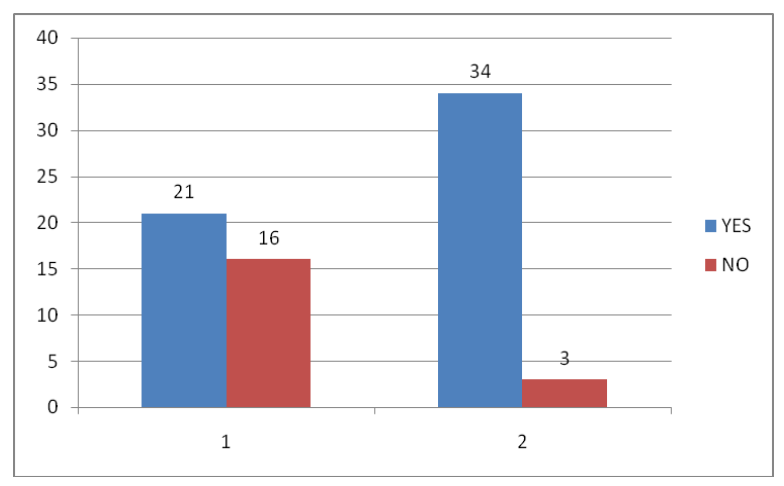

The chart clearly presents that the students also implemented the socioaffective strategies in their listening activities, although the strategies were mostly sometimes applied by the students, there were still more number applied the strategies, particularly in relation to the discussion done by the students with their classmates and teachers. It indicates that the learners keep trying to enhance their performances in listening.

\section{CONCLUSION}

Applying listening strategies can be influential factors affect the learners' performances in their listening activities, especially in anticipating and solving some problems that might appear in their listening practices. During the learners' participation in interpretative listening subject, the learners had been very familiar with the listening strategies; they did applied the strategies in their listening practices; metacognitive, cognitive, and socio-affective strategies. The learners had frequently applied the strategies whether in their prelistening, while listening, and post listening activities. The three-category of strategies, all of them had been applied based on the learners' needs. However, the teachers in the class needs to keep reminding and guiding the learners to apply the strategies because the learners sometimes ignore the strategies in their practices.

\section{REFERENCES}

Bang, Sujin \& Hiver, Phil. (2016). Investigating the structural relationships of cognitive and affective domains for L2 listening. Asian-Pacific Journal of Second and Foreign Language Education. DOI 10.1186/s40862-016-0013-8

Cohen, A. D. (2011a). L2 learner strategies. In E. Hinkel (Ed.), Handbook of Research in Second Language Teaching and Learning, Vol . I I Part V. Methods and Instruction in Second Language Teaching (pp. 681-698). Abingdon, England: Routledge.

Cross, J. (2009). Effects of listening strategy instruction on news videotext comprehension. Language

Teaching Research,13(2), 151176.

doi:http://dx.doi.org/10.1177/1362 168809103446.

Fang, X. (2008). Listening comprehension in EFL teaching. US-China Foreign Language, Vol 6, No.1, pp. 21-29. 
Hadijah \& Shalawati. 2016. A Study on Listening Skills and Perspectives to First Year Students at English Department of Academic Year 2015/2016. J-SHMIC (Journal of English for Academic). Vol. 3, No. 2 Agustus 2016.

Hadijah \& Shalawati. 2017. Listening Comprehension Hindrances of EFL (English Foregin Language) Learners on 2016/2017 Academic Year in English Study Program at Universitas Islam Riau. J-SHMIC (Journal of English for Academic). Vol. 4, No. 1 August 2017.

Nation, I. S. P. (2006). How large a vocabulary is needed for reading and listening? The Canadian Modern Language Review, 65,5982.

Vandergrift, Larry. (2007). Language Teaching. Recent development in second and foreign language listening comprehension research, page 191-210. United Kingdom: Cambridge University Press. doi:10.1017/S0261444807004338 